\title{
An empirical analysis on technophobia/ technophilia in consumer market segmentation
}

\author{
Adele Coppola ${ }^{*}$ and Fabio Verneau
}

\author{
* Correspondence: coppola@unina.it \\ Department of Agriculture, \\ Agricultural Economics and Policy \\ group, University of Naples Federico \\ II, Via Università 100, 80055, Portici \\ (Na), Italy
}

\begin{abstract}
Many factors can affect the success of food product innovations. One such factor is the role played by consumer attitudes and psychological factors, especially the way consumers feel towards technology, their attitude towards risk, and the perceived relationship between nutrition and health. With a view to analysing these factors, this paper first identifies consumer groups using a technophobia/technophilia scale and then relates attitude to technology with purchasing behaviour regarding products which have a higher level of manipulation. A set of statements based on the psychometric scale proposed by Cox and Evans was administered to a sample of 355 individuals intercepted as they left supermarkets and hypermarkets. Principal component analysis and cluster analysis were applied to identify groups of homogeneous individuals with regard to the behaviour of the interviewees in relation to technology. Results show the presence of seven different groups, including a small group of convinced technophiles (13\% of the sample). This group of early adopters can play an important role in promoting the use of innovative products, thereby contributing to a rapid increase in demand. Moreover, an important aspect was the result with respect to confidence attributed to the media in ensuring correct and unbiased information regarding new food technologies. Many of the respondents judged the media negatively in this respect. However, appropriate use of the media could be an important lever to counteract the attitude of caution or scepticism.
\end{abstract}

Keywords: Psychometric scale; Consumption choices; Food innovation

\section{Background}

Product innovation is a key feature in company development strategy. This especially holds true in the food industry where increasing competitiveness is occurring alongside a schizophrenic evolution of consumer demand where environmental, social and ethical concerns coexist with hedonism, interest in innovative food and alternative cuisines, and the spreading of new eating habits, such as vegetarianism and veganism, seems to occur alongside their traditional counterparts. As a fact, consumer demand appears to follow two divergent directions. On the one hand, there is an increasing demand for products with a high technological content which respond to consumer needs in terms of practicality of use, nutritional content and amount of specific molecules (functional products with low calorie content, enriched foods). On the other, consumers increasingly demand organic products, food that has natural requisites, which is produced with environmentally friendly techniques, as well as typical products

\section{Springer}

C 2014 Coppola and Verneau; licensee Springer. This is an open access article distributed under the terms of the Creative Commons Attribution License (http://creativecommons.org/licenses/by/2.0), which permits unrestricted use, distribution, and reproduction in any medium, provided the original work is properly cited. 
and locally grown products, for which knowledge of the production area and the underlying tradition are guarantees in themselves (Tenbült et al., 2005; Verhoog et al., 2003).

These different trends may be connected to the way in which consumers behave when faced with technology. Such behaviour influences how successful a new product can be: the failure rate of new products is known to be very high, with previous studies reporting different failure rates according to the country concerned or to the definitions adopted of "failure" and "success". The FAO background paper on "Food product innovation" (Winger and Wall 2006) reported that $50 \%$ of new food and drink products on grocery shelves are removed within two years. During 2000 and 2001 around 50\% to $67 \%$ of the new products were withdrawn within one year from the food retailing shelves in Germany, and similar figures, in most recent years (2010-2012), are reported with the reference to the US market (Mintel International Group Ltd 2013).

The factors of success as regards food product innovation have been extensively studied (Kleijnen et al. 2009; Betoret et al. 2011). Besides the role of food retailers and their "shelf position policy" (Winger and Wall 2006), and some characteristics of the market (existing market vs new market, competitive environment, potential size of the market), Balachandra and Friar (1997) pointed out the higher/lower ability of the new product to meet consumers' needs, the understanding of consumer wants and preferences, as well as the effectiveness of market segmentation and analysis. While market segmentation practices usually take into account socio-demographic features, the success of innovative foods can also depend on consumer attitudes and psychological factors, especially the way consumers feel towards technology, their attitude towards risk, and the perceived relationship between nutrition and health (Frewer et al. 2011; Rollin et al. 2011).

The latter aspects are the specific objects of our analysis. This paper aims, first of all, to ascertain whether it is possible to identify and characterise consumer groups using a technophobia/technophilia scale and, secondly, to correlate behaviour in relation to technology with consumption choices of products which have a different level of naturalness/manipulation. The degree of technophobia/technophilia was determined by referring to a psychometric scale (Food Technology Neophobia Scale, FTNS) set up by Cox and Evans 2008, based on a series of statements which aim to detect the individual's attitude towards risk, technology and science. The use of this scale is substantially based on the hypothesis that there is a positive correlation between a phobic attitude towards food with a high technological content, on the one hand, and a more general aversion to novelties and little confidence in science, on the other (Cox and Evans 2008; Evans et al. 2010a; Evans et al. 2010b). This paper used the set of statements proposed by Cox and Evans applying a principal component analysis to the statement scores obtained from a field survey and using a cluster analysis to identify groups of homogeneous individuals with regard to the individual's attitude towards risk, technology and science. The results of the analysis were then correlated with the consumption choices of some products, with a view to ascertaining the link between psychological aspects and consumption behaviour.

\section{Methods}

\subsection{Neophobia and psychometric scales}

In recent years the food sector has shown a highly innovative dynamic, and product innovation has become a strategic element for the competitiveness of food companies. 
The launch of new products is not always associated with a performance in the markets that rewards the costs on R \& D and in some cases highly innovative food in terms of the content of nutritional elements or of techniques used in processing is accepted with caution or is completely rejected by consumers. According to anthropologists, eating means "incorporating", carrying within one's own body (Fischler 1990), and this may entail a certain caution or also aversion regarding the introduction of new, unknown elements within a diet.

Aversion to new foods has been the subject of several studies aiming to identify which psychological and social variables affect more or less phobic behaviour related to food consumption and/or set up techniques and analytical instruments that might help identify segments of the population with a different degree of neophobia/neophilia in relation to foods and hence with a different propensity to purchase and consume innovative goods.

In the context of studies on consumer behaviour, various techniques have been proposed to summarise the emotional factors connected to consumption attitudes and the convictions of individuals (Siegrist et al. 2008). In particular, in the field of cognitive psychology, consumer science and marketing, so-called psychometric scales have been used due to their enhanced capacity to identify segments of the population which are more/less neophobic, with a view to identifying the "first adopters" of innovative products. Table 1 reports the main psychometric scales linked to the neophilia/neophobia dichotomy referring to the adoption of new technologies, confidence in science and acceptability of innovative foods. All the psychometric scales reported in the table use a set of statements on which interviewees have to express their level of agreement measured on a Likert scale ${ }^{\mathrm{a}}$.

One of the first attempts to adopt a psychometric scale to food sector in order to identify and measure the most important factors in risk perception resulting from food hazard and food technology is the Perceived Food Risk Index (PFRI) which was drawn up using as starting point the pioneering studies of Slovic (Slovic et al. 1986 ). Trust in Science Scale (TISS) is a six item scale which focuses on public attitudes toward controversial scientific research and technologies (Bak 2001). The Food Neophobia Scale (FNS) used by Pliner and Hobden (Pliner and Hobden 1992) is a psychometric scale very close to the FTNS which consists of 10 statements with a seven-point scale, from "strongly disagree" to "strongly agree", and which allows us to determine the level of food neophobia in relation to the greater/lesser willingness to try new foods. The FNS is a specific application to the food products of a previous scale (General Neophobia Scale - GNS) developed by the same authors. Also the GNS, which does not refer to specific product categories, consists of 10 items (Pliner and Hobden 1992).

Table 1 Main psychometric scales

\begin{tabular}{llll}
\hline Acronym & Full name & Scope of use & Authors \\
\hline FTNS & $\begin{array}{l}\text { Food technology } \\
\text { neophobia scale }\end{array}$ & $\begin{array}{l}\text { Measuring the degree of food neophobia } \\
\text { in humans linked to food technologies }\end{array}$ & $\begin{array}{l}\text { Cox, Cox and } \\
\text { Evans (2008) }\end{array}$ \\
\hline FNS & Food neophobia scale & $\begin{array}{l}\text { Measuring the degree of food neophobia } \\
\text { in humans linked to food }\end{array}$ & Pliner and Hobden (1992) \\
\hline GNS & General neophobia scale & Measuring the trait of neophobia in humans & Pliner and Hobden (1992) \\
\hline TISS & Trust in science scale & Measuring trust in science and technology & Bak (2001) \\
\hline PFRI & Perceived food risk index & Measuring consumer perception of food risk & Fife-Schaw and \\
& & & Rowe (1996) \\
\hline
\end{tabular}


Cox ed Evans measured correlations between FTNS, FNS, GNS, TISS and two different 'Willing to Try' scales, highlighting the strength of the FTNS scale in respect to predictive ability (Cox and Evans 2008). The FTNS is a useful tool to assess the impact of uncertainty and risk perception in relation to new technologies upon the acceptability of particular food. The FTNS has mainly been applied with reference to specific food technologies or certain types of foods linked to the use of sophisticated, new technological processes (Cox and Evans 2008; Evans et al. 2010a). However, further empirical testing of Cox's scale may be useful, first of all in relation to a set of foods rather than food technologies and, secondly, for a basket of common products which may be ordered on the basis of more/less technological content. This work concentrates specifically on these aspects.

\subsection{Objectives and methods}

This paper aims at analysing the relationship between the way consumers feels towards technology and consumption choices of products with a different level of naturalness/ manipulation.

We therefore performed an empirical analysis by means of a field survey based on administering a questionnaire. The survey was carried out in the region of Campania (southern Italy) and the interviews involved a sample of 355 individuals interviewed after shopping at supermarkets and hypermarkets. The composition of the sample was fairly balanced in terms of gender ( $48.7 \%$ men, $51.3 \%$ women) and over half the interviewees lived in the province of Naples. Other information on the socio-demographic characteristics of the interviewees may be noted in Table 2, showing certain specific features of the sample which help to interpret the survey results. First, the sample has a high share of self-employed workers $(42.5 \%)$ and graduates $(42.8 \%)$. Secondly, almost $60 \%$ of the interviewees are under 45 years old and in over two-thirds of cases the number of household members is equal to three or more. As regards monthly income, around one-third of the sample fell into each of the $€ 1,000-2,000$ and $€ 2,000-3,000$ classes.

The survey detected the opinions of consumers regarding categories of food products with a different technological content and related such opinions to their attitude to technology. In the first part of the questionnaire the interviewees were asked to express their level of agreement with a series of general statements on the role, importance and any effects of technology in the food sector. These statements were based on the set of 13 psychometric questions validated by Cox and Evans (2008). In the second part of the questionnaire, the survey focused on six product categories (functional products, organic, typical, short-chain, ready frozen food and diet products) to investigate specifically the confidence that the interviewee has in each type of food, the characteristics that can best describe it, and propensity and frequency of purchase.

The analysis on collected data was carried out in three steps.

First, an exploratory analysis was performed to understand how consumers feel about the proposed food categories, that is whether they are confident in them and how much they associate each product to a set of attributes (naturalness, safety, nutrition content, sense of gratification, taste, respect of the environment). To ascertain whether or not confidence in a product is associated to the opinion on the presence of a certain attribute a chi-square test was then carried out. A chi-square test was also used to verify the relationship between trust in a product category and the purchasing behaviour. 
Table 2 Socio-demographic characteristics of the sample interviewed

\begin{tabular}{|c|c|c|c|c|c|}
\hline Province & $\begin{array}{c}\text { No. of } \\
\text { interviewees }\end{array}$ & Percentage & Household income & $\begin{array}{c}\text { No. of } \\
\text { interviewees }\end{array}$ & Percentage \\
\hline Caserta & 20 & 5.63 & Up to 1000 euro & 46 & 13.0 \\
\hline Benevento & 26 & 7.32 & Between 1000 and 2000 euro & 122 & 34.4 \\
\hline Avellino & 39 & 10.99 & Between 2000 and 3000 euro & 131 & 36.9 \\
\hline Salerno & 76 & 21.41 & Over 3000 euro & 54 & 15.2 \\
\hline Napoli & 194 & 54.65 & No reply & 2 & 0.6 \\
\hline Total & 355 & 100.0 & Total & 355 & 100.0 \\
\hline Profession & $\begin{array}{c}\text { No. of } \\
\text { interviewees }\end{array}$ & Percentage & Household members & $\begin{array}{c}\text { No. of } \\
\text { interviewees }\end{array}$ & Percentage \\
\hline Unemployed & 8 & 2.30 & 1 & 34 & 9.6 \\
\hline Manager & 15 & 4.20 & 2 & 73 & 20.6 \\
\hline Other & 21 & 5.90 & 3 & 87 & 24.5 \\
\hline Employee & 78 & 22.00 & 4 & 102 & 28.7 \\
\hline Not in workforce & 81 & 22.80 & 5 and over & 59 & 16.6 \\
\hline Self-employed & 151 & 42.50 & & & \\
\hline Total & 355 & 100.0 & Total & 355 & 100.0 \\
\hline Age class & $\begin{array}{c}\text { No. of } \\
\text { interviewees }\end{array}$ & Percentage & Qualification & $\begin{array}{c}\text { No. of } \\
\text { interviewees }\end{array}$ & Percentage \\
\hline Up to 35 years & 117 & 33.0 & Primary & 11 & 3.1 \\
\hline $36-45$ years & 93 & 26.2 & Lower secondary & 56 & 15.8 \\
\hline 46 - 55 years & 94 & 26.5 & Higher secondary & 136 & 38.3 \\
\hline Over 55 years & 51 & 14.4 & Degree & 152 & 42.8 \\
\hline Total & 355 & 100.0 & Total & 355 & 100.0 \\
\hline
\end{tabular}

A second step of the analysis aimed to classify the interviewees according to their attitude towards technology and risk, measured by means of the 13 psychometric questions proposed by Cox and Evans. In this analysis, using principal component analysis (PCA) the 13 psychometric questions were grouped so as to specify complex indicators that might identify the way individuals relate to certain issues. On the basis of these complex indicators, the interviewees were classified into groups which are characterised by a different attitude to technology.

In the third and last step, groups of consumers, identified in step two, were related to the purchasing behaviour to verify by means of a chi square test whether the different attitude towards technology and risk actually influences the purchasing frequency of food with a higher/lower manipulation level.

\section{Results}

Analysis of the responses shows clearly differentiated opinions between organic, shortchain and typical products, on the one hand, and the food categories undergoing greater handling/processing, on the other. Whereas the first three categories of products were trusted by over $80 \%$ of the interviewees, over $50 \%$ responded that they had no confidence in foods with greater technological content, with a percentage that reached $61 \%$ in the case of ready frozen foods (Figure 1 ).

The dichotomy observed in terms of confidence also emerges in the analysis of attributes associated to the various product categories when the issue is naturalness 


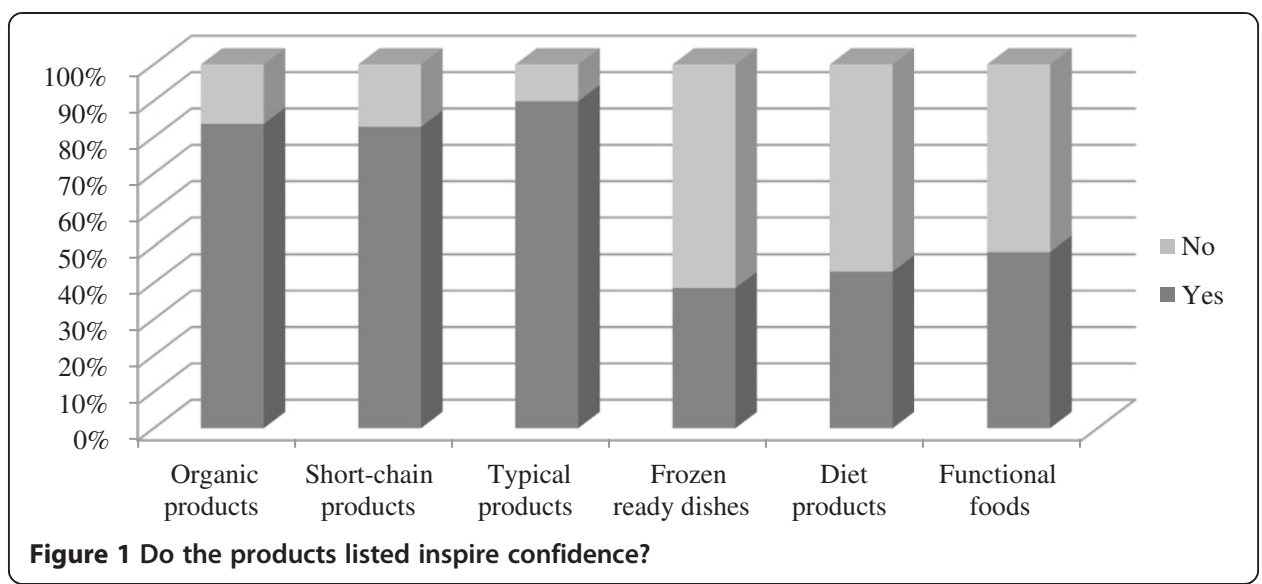

(Figure 2). Naturalness is the element which, according to the interviewees, clearly distinguishes organic, short-chain and typical products from the three other categories. Indeed, it is on the naturalness attribute that, as will be seen below, confidence in the former is based. The opinion on naturalness, which in this dichotomy appears to take on an ideological connotation, is reflected, at least for organic and short-chain products, in the responses concerning environmental respect. What is less clear, however, is the opinion on the other attributes in question, and it should be stressed that safety is associated to functional foods by a percentage of interviewees which does not differ greatly from that measured for organic products. Moreover, Figure 2 shows that consumers characterize each of the product categories with only few distinctive attributes: as an example, while organic products are mostly natural and safe, frozen ready dishes are mainly perceived as gratifying and tasty, and functional food are safe and nutritious.

To determine on which attributes the consumer bases the greatest/lowest trust in a product category, for each attribute we crossed the responses obtained as regards confidence with those concerning the most significant characteristics. The relations between the variables analysed were subjected to the chi-square test in order to ascertain whether or not confidence in a product is associated to the opinion on the presence of

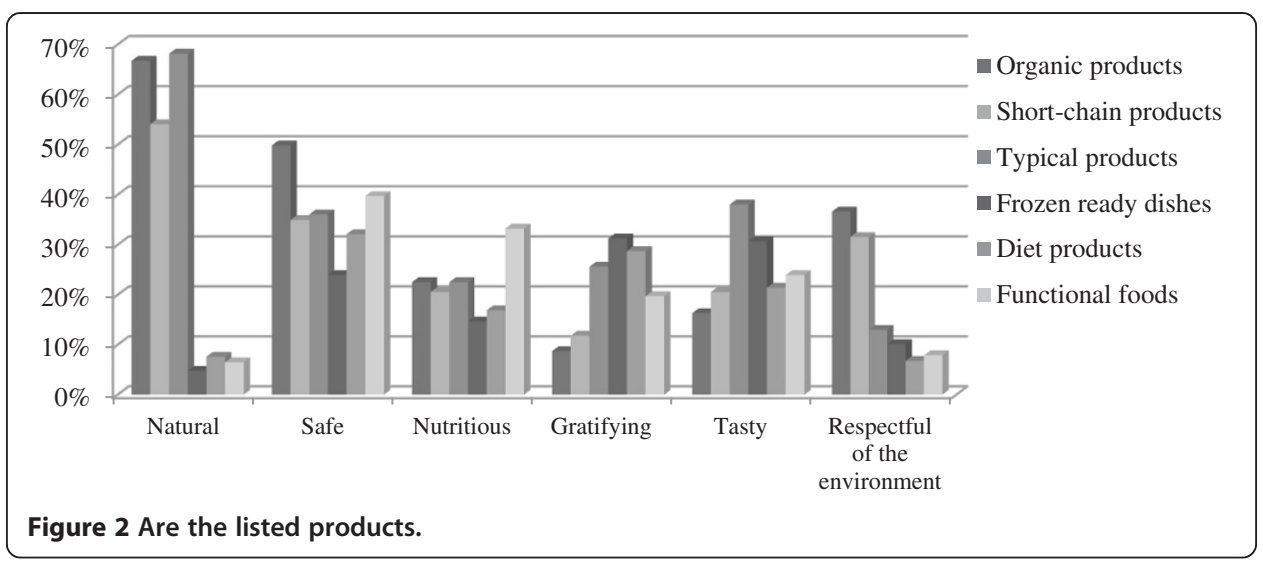


a certain attribute. The main results of the analysis are shown in Table 3 where values are reported only in case of significant relationships. What emerges is that:

- for organic products there is a significant relation between consumer confidence and their naturalness and safety. On analysing the specific data of the contingency tables, naturalness is shown to be a characterising element of organic products for $75 \%$ of those who trust such foods, against $26 \%$ who responded that they did not trust them;

- for functional foods the chi-square test shows a link between the presence or otherwise of confidence on the part of the interviewees and all the attributes investigated, except for the aspects that concern gratification and respect for the environment. The type of link may be made clearer by the percentages in question: $58 \%$ and $45 \%$ of those who trust functional foods believe that these products are, respectively, safe and nutritious;

- $73 \%$ of the interviewees who have confidence in typical products consider naturalness their distinctive element; only $22 \%$ of those who state they have no confidence in such products underline their naturalness as an attribute characterising this class of goods;

- a link between confidence and respect for the environment is statistically significant for short-chain and typical products, but this attribute seems to play a small role: only $34.4 \%$ of interviewees who trust in short-chain products state that they help the environment and the percentage is even smaller $(11.9 \%)$ in the case of typical products;

- confidence and judgement on product safety are statistically related for all classes of food, but this attribute seems to be very important in case of organic, diet and functional products. Anyway, it should be underlined that for the last two products

Table 3 Confidence vs. attributes for various product categories by product category: contingence table*

\begin{tabular}{|c|c|c|c|c|c|c|c|c|c|c|c|c|c|}
\hline & & \multicolumn{2}{|c|}{$\begin{array}{l}\text { Are they } \\
\text { natural? }\end{array}$} & \multicolumn{2}{|c|}{$\begin{array}{l}\text { Are they } \\
\text { safe? }\end{array}$} & \multicolumn{2}{|c|}{$\begin{array}{c}\text { Are they } \\
\text { nutritious? }\end{array}$} & \multicolumn{2}{|c|}{$\begin{array}{l}\text { Are they } \\
\text { gratifying? }\end{array}$} & \multicolumn{2}{|c|}{$\begin{array}{c}\text { Are they } \\
\text { flavoursome? }\end{array}$} & \multicolumn{2}{|c|}{$\begin{array}{c}\text { Do they } \\
\text { help the } \\
\text { environment? }\end{array}$} \\
\hline & & No & Yes & No & Yes & No & Yes & No & Yes & No & Yes & No & Yes \\
\hline \multirow{2}{*}{$\begin{array}{l}\text { Do you trust } \\
\text { organic } \\
\text { products? }\end{array}$} & No & $74.1 \%$ & $25.9 \%$ & $75.9 \%$ & $24.1 \%$ & & & & & & & & \\
\hline & Yes & $25.3 \%$ & $74.7 \%$ & $45.1 \%$ & $54.9 \%$ & & & & & & & & \\
\hline \multirow{2}{*}{$\begin{array}{l}\text { Do you trust } \\
\text { short-chain } \\
\text { products? }\end{array}$} & No & $55.7 \%$ & $44.3 \%$ & $77.0 \%$ & $23.0 \%$ & & & & & & & $82.0 \%$ & $18.0 \%$ \\
\hline & Yes & $43.9 \%$ & $56.1 \%$ & $62.6 \%$ & $37.4 \%$ & & & & & & & $65.6 \%$ & $34.4 \%$ \\
\hline \multirow{2}{*}{$\begin{array}{l}\text { Do you trust } \\
\text { typical } \\
\text { products? }\end{array}$} & No & $77.8 \%$ & $22.2 \%$ & $77.8 \%$ & $22.2 \%$ & & & & & & & $77.8 \%$ & $22.2 \%$ \\
\hline & Yes & $26.6 \%$ & $73.4 \%$ & $62.4 \%$ & $37.6 \%$ & & & & & & & $88.1 \%$ & $11.9 \%$ \\
\hline \multirow{2}{*}{$\begin{array}{l}\text { Do you trust } \\
\text { frozen ready } \\
\text { dishes? }\end{array}$} & No & & & $79.8 \%$ & $20.2 \%$ & & & $65.1 \%$ & $34.9 \%$ & & & & \\
\hline & Yes & & & $70.1 \%$ & $29.9 \%$ & & & $74.5 \%$ & $25.5 \%$ & & & & \\
\hline \multirow{2}{*}{$\begin{array}{l}\text { Do you } \\
\text { trust diet } \\
\text { products? }\end{array}$} & No & $95.0 \%$ & $5.0 \%$ & $77.7 \%$ & $22.3 \%$ & $87.6 \%$ & $12.4 \%$ & & & & & & \\
\hline & Yes & $88.9 \%$ & $11.1 \%$ & $54.9 \%$ & $45.1 \%$ & $77.1 \%$ & $22.9 \%$ & & & & & & \\
\hline \multirow{2}{*}{$\begin{array}{l}\text { Do you trust } \\
\text { functional } \\
\text { foods? }\end{array}$} & No & $97.3 \%$ & $2.7 \%$ & $77.6 \%$ & $22.4 \%$ & $77.6 \%$ & $22.4 \%$ & & & $66.1 \%$ & $33.9 \%$ & & \\
\hline & Yes & $89.5 \%$ & $10.5 \%$ & $41.9 \%$ & $58.1 \%$ & $55.2 \%$ & $44.8 \%$ & & & $86.6 \%$ & $13.4 \%$ & & \\
\hline
\end{tabular}

*Only statistically significant relationships are included in the table. 
the share of confident respondents is very low and safety assumes, then, a very slight role (see Figure 2).

Purchase frequency is statistically related to trust in the product (Table 4). This holds especially for functional foods as $42 \%$ of those who do not buy this type of product state that the lack of trust is the main motivation.

The attitude towards risk and technology can be inferred from the descriptive statistics in the Cox and Evans' scale (Table 5). Mean answers to the psychometric questions are very close to one another and always attain a score higher than 4, except for the perception of the effects on health in the long term and confidence in the media (3.69 and 3 respectively). The feeling of uncertainty seems to prevail in influencing the approach towards food technology. About $70 \%$ of the interviewees agree, to a greater or lesser extent, that new food technologies are something they are unsure of. This can be related to the fact that the benefits of new food technologies are often over-rated for $68.7 \%$ of the sample, that it may be risky to shift too hastily towards new food technology (58\% of the sample), while only $36.6 \%$ of interviewees agree that new food technologies will not have negative effects on health in the long term.

Answers to psychometric statements are summarised by principal component analysis. The factor loading matrix (Table 6) reports the correlation coefficients between the 13 statements surveyed and the four components extracted in the PCA and allows the significance of the components to be ascertained. The first three express three different dimensions on which to construct perception of technology on the part of the consumer: riskiness, utility and the human possibility of controlling processes.

Table 4 Confidence vs purchase frequency by product category: contingence table and results of the chi-squared test

\begin{tabular}{|c|c|c|c|c|c|}
\hline & & \multicolumn{2}{|c|}{ Purchase frequency } & \multirow[t]{2}{*}{ chi-square } & \multirow[t]{2}{*}{ p-value } \\
\hline & & Never or rarely & Often & & \\
\hline \multirow[t]{3}{*}{ Do you trust organic products? } & No & $67,2 \%$ & $32,8 \%$ & 34,642 & 0,000 \\
\hline & Yes & $27,3 \%$ & $72,7 \%$ & & \\
\hline & Total & $33,8 \%$ & $66,2 \%$ & & \\
\hline \multirow[t]{3}{*}{ Do you trust short-chain products? } & No & $55,7 \%$ & $44,3 \%$ & 8,816 & 0,003 \\
\hline & Yes & $35,4 \%$ & $64,6 \%$ & & \\
\hline & Total & $38,9 \%$ & $61,1 \%$ & & \\
\hline \multirow[t]{3}{*}{ Do you trust typical products? } & No & $55,6 \%$ & $44,4 \%$ & 19,312 & 0,000 \\
\hline & Yes & $21,9 \%$ & $78,1 \%$ & & \\
\hline & Total & $25,4 \%$ & $74,6 \%$ & & \\
\hline \multirow[t]{3}{*}{ Do you trust frozen ready dishes? } & No & $69,3 \%$ & $30,7 \%$ & 41,684 & 0,000 \\
\hline & Yes & $34,3 \%$ & $65,7 \%$ & & \\
\hline & Total & $55,8 \%$ & $44,2 \%$ & & \\
\hline \multirow[t]{3}{*}{ Do you trust diet products? } & No & $69,3 \%$ & $30,7 \%$ & 30,716 & 0,000 \\
\hline & Yes & $39,9 \%$ & $60,1 \%$ & & \\
\hline & Total & $56,6 \%$ & $43,4 \%$ & & \\
\hline \multirow[t]{3}{*}{ Do you trust functional foods? } & No & $71,6 \%$ & $28,4 \%$ & 54,172 & 0,000 \\
\hline & Yes & $32,6 \%$ & $67,4 \%$ & & \\
\hline & Total & $52,7 \%$ & $47,3 \%$ & & \\
\hline
\end{tabular}


Table 5 Cox and Evans' scale: percentage of respondents and mean value

\begin{tabular}{|c|c|c|c|c|c|c|c|c|}
\hline & 1 & 2 & 3 & 4 & 5 & 6 & & Mean \\
\hline & $\begin{array}{c}\text { Totally } \\
\text { disagree (\%) }\end{array}$ & & & $\begin{array}{l}\text { Neither agree } \\
\text { nor disagree (\%) }\end{array}$ & & & $\begin{array}{c}\text { Totally } \\
\text { agree (\%) }\end{array}$ & \\
\hline $\begin{array}{l}\text { It may be risky to shift too hastily } \\
\text { towards new food technology }\end{array}$ & 5.4 & 10.4 & 10.4 & 15.5 & 20.6 & 23.1 & 14.6 & 4.63 \\
\hline $\begin{array}{l}\text { New food technologies in the } \\
\text { long term may have negative } \\
\text { effects on the environment }\end{array}$ & 4.5 & 8.5 & 8.5 & 16.9 & 23.1 & 24.8 & 13.8 & 4.75 \\
\hline $\begin{array}{l}\text { Society should not depend so } \\
\text { greatly on new technologies to } \\
\text { solve food issues }\end{array}$ & 3.7 & 14.4 & 7.9 & 15.5 & 19.2 & 19.2 & 20.3 & 4.71 \\
\hline $\begin{array}{l}\text { There are many tasty, nutritious } \\
\text { foods around, so we do not } \\
\text { need to use new food } \\
\text { technologies to produce others }\end{array}$ & 5.6 & 9.0 & 9.3 & 16.1 & 25.4 & 23.1 & 11.5 & 4.62 \\
\hline $\begin{array}{l}\text { New food products are no more } \\
\text { healthy than traditional foods }\end{array}$ & 5.1 & 10.1 & 4.8 & 16.3 & 27.0 & 24.5 & 12.1 & 4.72 \\
\hline $\begin{array}{l}\text { The benefits of new food } \\
\text { technologies are often over-rated }\end{array}$ & 2.0 & 7.3 & 7.9 & 14.1 & 28.5 & 25.9 & 14.4 & 4.95 \\
\hline $\begin{array}{l}\text { New food technologies are } \\
\text { something I'm unsure about }\end{array}$ & 4.8 & 4.2 & 9.3 & 11.0 & 33.5 & 23.7 & 13.5 & 4.89 \\
\hline $\begin{array}{l}\text { New food technologies diminish } \\
\text { the natural quality of food }\end{array}$ & 5.4 & 14.4 & 4.5 & 13.5 & 20.0 & 26.8 & 15.5 & 4.62 \\
\hline $\begin{array}{l}\text { I have no reason to try highly } \\
\text { technological foods because } \\
\text { those that I eat are already good } \\
\text { enough }\end{array}$ & 5.6 & 9.0 & 9.3 & 16.1 & 25.4 & 23.1 & 11.5 & 4.89 \\
\hline $\begin{array}{l}\text { New food technologies ensure } \\
\text { that we all have greater control } \\
\text { over food choices }\end{array}$ & 5.4 & 13.2 & 16.9 & 17.7 & 24.5 & 16.6 & 5.6 & 4.15 \\
\hline $\begin{array}{l}\text { The products obtained with new } \\
\text { food technologies may help } \\
\text { people to follow a balanced diet }\end{array}$ & 5.1 & 14.6 & 12.1 & 18.0 & 24.8 & 18.9 & 6.5 & 4.25 \\
\hline $\begin{array}{l}\text { New food technologies will not } \\
\text { have negative effects on health } \\
\text { in the long term }\end{array}$ & 9.9 & 23.9 & 9.6 & 20.0 & 22.8 & 8.5 & 5.4 & 3.69 \\
\hline $\begin{array}{l}\text { The media usually give correct } \\
\text { impartial news on new food } \\
\text { technologies }\end{array}$ & 21.1 & 35.5 & 13.2 & 4.5 & 10.4 & 8.2 & 7.0 & 3.00 \\
\hline
\end{tabular}

The first component explains $25.7 \%$ of the total variance and is correlated positively with the statements "It may be risky to shift too hastily towards new food technology" and "New food technologies in the long term may have negative effects on the environment". The component identifies the link between technology and risk perception (Siegrist 2008): introduction of new technologies in the food sector is interpreted as a factor aggravating existing risks, and the component which gradually shifts from negative to positive values captures the degree of risk aversion. This significance is also underlined by another question which has a high correlation index (even if it comes more into play in the second component) and which associates an idea of uncertainty to the new technologies. An important contribution to the first component is made by two other questions. The first expresses the opinion that society should not depend on new technologies to solve food issues. This statement may also be connected to risk perception: food safety is a strategic objective for society and should not depend on 


\begin{tabular}{|c|c|c|c|c|}
\hline & \multicolumn{4}{|c|}{ Components } \\
\hline & 1 & 2 & 3 & 4 \\
\hline & $\begin{array}{c}\text { Risk } \\
\text { perception }\end{array}$ & $\begin{array}{l}\text { Perception } \\
\text { of futility of } \\
\text { technologies }\end{array}$ & $\begin{array}{l}\text { Perception } \\
\text { of benefits }\end{array}$ & $\begin{array}{l}\text { Trust in } \\
\text { the role of } \\
\text { information }\end{array}$ \\
\hline $\begin{array}{l}\text { It may be risky to shift too hastily towards new food } \\
\text { technology }\end{array}$ & 0.777 & 0.122 & 0.003 & -0.141 \\
\hline $\begin{array}{l}\text { New food technologies in the long term may have } \\
\text { negative effects on the environment }\end{array}$ & 0.707 & -0.045 & -0.144 & 0.026 \\
\hline $\begin{array}{l}\text { Society should not depend so greatly on new } \\
\text { technologies to solve food issues }\end{array}$ & 0.669 & 0.145 & 0.123 & -0.027 \\
\hline $\begin{array}{l}\text { There are many tasty, nutritious foods around, so } \\
\text { we do not need to use new food technologies } \\
\text { to produce others }\end{array}$ & 0.479 & 0.353 & -0.341 & 0.114 \\
\hline $\begin{array}{l}\text { New food products are no more healthy than } \\
\text { traditional foods }\end{array}$ & -0.136 & 0.736 & 0.049 & -0.107 \\
\hline $\begin{array}{l}\text { The benefits of new food technologies are often } \\
\text { over-rated }\end{array}$ & 0.141 & 0.673 & -0.120 & -0.042 \\
\hline $\begin{array}{l}\text { New food technologies are something I'm unsure } \\
\text { about }\end{array}$ & 0.447 & 0.563 & 0.039 & 0.124 \\
\hline $\begin{array}{l}\text { New food technologies diminish the natural } \\
\text { quality of food }\end{array}$ & 0.439 & 0.514 & -0.258 & -0.003 \\
\hline $\begin{array}{l}\text { I have no reason to try highly technological foods } \\
\text { because those that I eat are already good enough }\end{array}$ & 0.315 & 0.510 & -0.067 & 0.395 \\
\hline $\begin{array}{l}\text { New food technologies ensure that we all have } \\
\text { greater control over food choices }\end{array}$ & 0.026 & -0.091 & 0.792 & 0.080 \\
\hline $\begin{array}{l}\text { The products obtained with new food technologies } \\
\text { may help people to follow a balanced diet }\end{array}$ & -0.054 & -0.152 & 0.689 & 0.250 \\
\hline $\begin{array}{l}\text { New food technologies will not have negative } \\
\text { effects on health in the long term }\end{array}$ & -0.071 & 0.193 & 0.621 & -0.432 \\
\hline $\begin{array}{l}\text { The media usually give correct, impartial news on } \\
\text { new food technologies }\end{array}$ & -0.136 & 0.002 & 0.167 & 0.804 \\
\hline
\end{tabular}

Kaiser-Meyer-Olkin Measure of Sampling Adequacy $=0.746$. Bartlett's Test of Sphericity $=853$. $\mathrm{df}=70 ; \mathrm{p}<0.0001$.

Explained variance $56 \%$.

technologies that are considered unreliable. The other statement "There are many tasty, nutritious foods around, so we do not need to use new food technologies to produce others" shows an aversion to technology in general and adds an ideological connotation to the first component.

The high levels of uncertainty and scarce perception of tangible benefits may generate in consumers the idea that new food technologies are superfluous. This is condensed in the second factor (12.2\% of total variance) which captures the opinion of the interviewees as regards the usefulness of adopting new food technologies, and in general captures the level of uncertainty connected to them (perception of futility of technologies). When it takes on positive values, the second component identifies consumers who do not recognise a real benefit in the introduction of new technologies in food production. This approach is further reinforced by the feeling of uncertainty which goes with it ("New food technologies are something I'm unsure about") (Hansen et al. 2003; Frewer and Salter 2003). By contrast, negative values of the component are linked to the recognition by the interviewees that new technologies actually bring about a benefit in terms of health, food taste and quality. 
The positive contribution that new technologies may make is better summarised in the third component (perception of benefits, explaining 9.5\% of variance), correlated to the perception of benefits that new technologies have in terms of control over food choices, their capacity to ensure a balanced diet and the fact that they lead to positive effects on health (Weber et al. 2002).

The fourth and last component (8.5\% of total variance) deviates from the others and puts the stress primarily on the role that the media may play in giving balanced and not biased information (trust in the role of information). This role appears particularly important as the component is also linked with the opinion on the effects which the new technologies may have on health. As one shifts from negative to positive values of the component, the trust in the media thus rises, as does the idea that in the long term new food technologies will have negative effects on health. This link, on one side, is coherent with the role media have played in many Italian food scandals, on the other side suggests how media are able to build a confidence feeling more on "bad news" than on information by itself.

In the second phase of the analysis the components extracted, starting from the psychometric questions, were used to classify the interviewees on the basis of their overall attitude to food technologies. Based on a hierarchical classification technique and choosing the number of groups where there is the maximum gap ${ }^{b}$, we identified seven groups whose characteristics may be traced by looking at the centroid, in other words the average value which the components assume for each of them (Table 7), and, for a greater detail, at the mean scores attributed to the psychometric questions (Table 8).

Tables 9 and 10 report schematically the statements and characterising elements of the various groups. The first distinction among the interviewees in the groups may be made in relation to the degree of risk perception (component 1). In respect of this element, we may separate groups 3 and 6, which are both distinguished by negative values for this component, from the other groups for which the degree of risk perception is gradually increasing. Thus, except for groups 3 and 6, the sense of uncertainty and concern over the effects that new technologies could have in the future evidently prevails, to a greater or lesser extent, in all the interviewees.

Only for Group 3 (13\% of the interviewed sample) can one speak of an actual technophile attitude ${ }^{c}$ as a low perception of risk goes together with the recognition of the objective benefits in terms of food quality and contribution to diet. In Group 6 (17\% of the sample), although there is no underlying concern or ideological preclusion in respect of food technologies, there emerges substantial scepticism on the utility of product

Table 7 Cluster analysis results

\begin{tabular}{lccccc}
\hline & $\begin{array}{c}\text { Size of } \\
\text { group }\end{array}$ & $\begin{array}{c}\text { Risk } \\
\text { perception }\end{array}$ & $\begin{array}{c}\text { Perception of futility } \\
\text { of technologies }\end{array}$ & $\begin{array}{c}\text { Perception } \\
\text { of benefits }\end{array}$ & $\begin{array}{c}\text { Trust in the } \\
\text { role of information }\end{array}$ \\
\hline Group 1 & 14 & 1.190 & -1.741 & 1.614 & 0.923 \\
Group 2 & 59 & 0.551 & 0.641 & -0.921 & 0.481 \\
Group 3 & 48 & -1.096 & -0.814 & 0.303 & -0.757 \\
Group 4 & 95 & 0.185 & 0.133 & 0.115 & -0.762 \\
Group 5 & 32 & 0.675 & -1.291 & -1.313 & 0.043 \\
Group 6 & 60 & -0.951 & 0.252 & -0.029 & 1.080 \\
Group 7 & 47 & 0.454 & 0.833 & 1.064 & 0.025 \\
\hline
\end{tabular}

Group size (no.) and centroids per group. 
Table 8 Mean value of answers to psychometric questions by group

\begin{tabular}{|c|c|c|c|c|c|c|c|}
\hline & \multicolumn{7}{|c|}{ Group } \\
\hline & 1 & 2 & 3 & 4 & 5 & 6 & 7 \\
\hline It may be risky to shift too hastily towards new food technology & 6.0 & 5.5 & 2.9 & 5.1 & 5.3 & 3.0 & 5.6 \\
\hline $\begin{array}{l}\text { New food technologies in the long term may have negative effects on } \\
\text { the environment }\end{array}$ & 5.1 & 5.4 & 3.4 & 5.2 & 5.8 & 3.6 & 5.2 \\
\hline $\begin{array}{l}\text { Society should not depend so greatly on new technologies to solve } \\
\text { food issues }\end{array}$ & 6.3 & 5.5 & 3.6 & 5.0 & 4.4 & 3.8 & 5.2 \\
\hline $\begin{array}{l}\text { There are many tasty, nutritious foods around, so we do not need to } \\
\text { use new food technologies to produce others }\end{array}$ & 4.2 & 6.0 & 2.9 & 4.5 & 5.4 & 4.0 & 5.2 \\
\hline New food products are no more healthy than traditional foods & 2.1 & 5.5 & 4.0 & 5.1 & 2.3 & 5.0 & 5.8 \\
\hline The benefits of new food technologies are often over-rated & 2.8 & 5.6 & 4.1 & 5.0 & 4.5 & 5.0 & 5.8 \\
\hline New food technologies are something I'm unsure about & 5.0 & 5.9 & 3.3 & 5.0 & 4.0 & 4.8 & 5.7 \\
\hline New food technologies diminish the natural quality of food & 2.5 & 6.2 & 2.7 & 4.8 & 5.1 & 4.4 & 5.5 \\
\hline $\begin{array}{l}\text { I have no reason to try highly technological foods because those that } \\
\text { I eat are already good enough }\end{array}$ & 4.6 & 6.2 & 3.1 & 4.8 & 4.3 & 5.1 & 5.6 \\
\hline $\begin{array}{l}\text { New food technologies ensure that we all have greater control over } \\
\text { food choices }\end{array}$ & 6.4 & 2.9 & 4.5 & 4.2 & 2.7 & 4.2 & 5.6 \\
\hline $\begin{array}{l}\text { The products obtained with new food technologies may help people } \\
\text { to follow a balanced diet }\end{array}$ & 6.5 & 3.4 & 4.5 & 3.8 & 3.4 & 4.6 & 5.4 \\
\hline $\begin{array}{l}\text { New food technologies will not have negative effects on health in } \\
\text { the long term }\end{array}$ & 4.3 & 2.2 & 4.4 & 4.6 & 1.9 & 3.0 & 4.9 \\
\hline The media usually give correct impartial news on new food technologies & 4.7 & 3.1 & 2.2 & 1.9 & 2.4 & 5.0 & 3.2 \\
\hline
\end{tabular}

innovations. By contrast, a convinced technophobe attitude is found in Group 2 (16\% of interviewees) in which a high perception of risk and concern with the long-term effects on health and the environment accompany the idea of the futility of technology and the absence of benefits for diet and food choices. In the other groups these elements are combined with different intensities and make cautious attitudes emerge, yet which are more or less open to new technologies due to their ascribed benefits or the quality of the food or health aspects linked to them.

A particular aspect that should be stressed concerns the degree of trust attributed to the media in ensuring the new food technologies are covered correctly and impartially (component 4). Many of the interviewees expressed themselves negatively as regards the media, except for Groups 1 and 6 who believe that in the field of food technologies the media play a major role in information terms. Importantly, information could be an important lever to act on the attitude of caution or scepticism as regards new products which characterises these two groups, that accounts overall for one fifth of the sample.

Confirmation of the results of the group analysis was sought by linking the extreme groups $^{\mathrm{d}}$ (the convinced technophobes and the convinced technophiles) to purchase of products with a higher level of manipulation, that is, functional, light and ready to eat and frozen products. Indeed, extreme groups are those where the mean values of all the principal components (the centroids) have opposite signs, and thus attitude to food technology should be better defined. For the extreme groups Table 11 reports the percentage of people purchasing, or otherwise, the three food categories. In all cases the convinced technophobes show a higher, and statistically different, percentage of nonbuying interviewees with respect to the convinced technophile group. This particularly holds for diet products where $94 \%$ of the group states that they buy them, while the percentage reaches only $58 \%$ within the convinced technophobes. 
Table 9 Characterising statements by group

\begin{tabular}{ll}
\hline Group & Characterising aspects \\
\hline Group 1 & They perceive in great measure the risk and uncertainty associated to new \\
technologies. Yet, at the same time, they think that products obtained with new \\
technologies may have beneficial effects on diet and allow control of food \\
choices. They do not believe that in the long term product innovations can have \\
negative effects on health. They trust the role that the media perform in \\
supplying sound information. Almost $64 \%$ of the group have children under \\
12 years old.
\end{tabular}

Group 2 There is a strong perception of risk and uncertainty associated to new technologies, but what prevails is the idea of their uselessness because they do not provide more tasty or healthy products, nor do they allow the diet to be controlled. They believe that in the long run new food technologies may have negative effects on health and the environment.

Group 3 They do not consider food technology risky and do not associate uncertainty to it. They consider product innovations useful because they lead to tasty, betterquality food and allow greater control over diet. They do not think that, in the long term, technology can be detrimental to health. They have no confidence in the informational role of the media. Over $60 \%$ of Group 3 have a university degree.

Group 4 They represent the mid-point of the sample and summarise commonly-shared opinions on new food technology. Worried about the effects on health and the environment, they believe that traditional foods are better and more healthy, and that the benefits of the new technology are overrated. They are distinguished by their total lack of confidence in the ability of the media to supply correct, impartial information on new food technologies. Only $28 \%$ of the group have a university degree.

Group 5 They have a high perception of the risk associated with food technologies and are concerned at the negative effects they might have on the environment and health. They have no confidence in the ability of new foods to contribute to a more balanced diet, but admit that new products may be more tasty and healthy. They have no confidence in the ability of the media to provide reliable information on such technologies.

Group 6 They are not ideologically opposed to new food technologies: they do not consider it risky to adopt new technologies too hastily and are not concerned by dependence upon them to solve food problems. However, they do not think that innovations in the food sector are useful. They believe their benefits are overestimated and think it is possible to find products that are already quite good. In general, there are uncertain regarding new technologies and fear negative long-term effects on health. Males make up 68\% of the group.

Group 7 This group perceives the benefits that technological foods may confer in terms of controlling food choices and achieving a balanced diet. Nevertheless they consider new food technologies risky and essentially futile as they think that they diminish the natural quality of food and that there are already good, healthier technophobes

\section{Definition}

Cautious

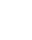
products on the market. Females make up $63.8 \%$ of this group.

Tendency to

be technophobic

Convinced technophiles

Traditionalists

\section{Sceptics}

Tendency to be technophile

Table 10 Socio-demographic statistics by group

\begin{tabular}{|c|c|c|c|}
\hline Group & Females (\%) & Graduates (\%) & Families with chidren (\%) \\
\hline Cautious & 57.1 & 57.1 & 64.3 \\
\hline Convinced technophobes & 47.5 & 50.8 & 30.5 \\
\hline Convinced technophiles & 41.7 & 62.5 & 22.9 \\
\hline Traditionalists & 63.2 & 28.4 & 23.2 \\
\hline Tendency to be tecnophobic & 53.1 & 40.6 & 28.1 \\
\hline Sceptics & 31.7 & 35.0 & 33.3 \\
\hline Tendency to be technophile & 63.8 & 48.9 & 19.1 \\
\hline
\end{tabular}


Table 11 Purchasing behaviour in convinced technophobe/technophile groups

\begin{tabular}{lccccc}
\hline Do you buy?... & & Convinced technophobes & Convinced technophiles & $\mathbf{X}^{\mathbf{2}}$ & p-value \\
\hline Frozen ready dishes & No & $30.5 \%$ & $8.3 \%$ & 7.968 & 0.005 \\
& Yes & $69.5 \%$ & $91.7 \%$ & & \\
& & $100.0 \%$ & $100.0 \%$ & & \\
\hline Diet products & No & $42.4 \%$ & $6.3 \%$ & 17.875 & 0.000 \\
& Yes & $57.6 \%$ & $93.7 \%$ & & \\
& & $100.0 \%$ & $100.0 \%$ & & \\
\hline Functional food & No & $35.6 \%$ & $16.7 \%$ & 4.799 & 0.028 \\
& Yes & $64.4 \%$ & $83.3 \%$ & & \\
& & $100.0 \%$ & $100.0 \%$ & & \\
\hline
\end{tabular}

\section{Discussion and conclusions}

The relationship between attitudes, intentions and behaviour is extensively covered in the literature and has been one of the chief aspects tackled by consumer studies in the economic and social field for the past 25 years. The addition of attitudinal and psychographic factors to the socio-demographic variables traditionally used by economic theory has led to the progressive development of psychometric scales to capture conceptual dimensions which are able to interpret value systems, lifestyles and attitudes, and translate them into measurable variables.

The use of psychometrics in the social sciences, economics and marketing has at times focused on the dichotomy between technophobe and technophile attitudes in the food sector. The prevalence of one or the other may greatly affect the choices and performance of the food industry interested in R\&D investment to introduce highly innovative products onto the market. Identification and quantification of the market segments most attracted by innovative products, combined with analysis of the sociodemographic, behavioural and psychographic characteristics in such groups, may steer company choices both in terms of investment and communication strategies.

Our study falls within the above research strand. The aim was to segment a sample of consumers in the southern Italian region of Campania on the basis of their degree of technophobia in the food sector. Our analysis was conducted using the psychometric scale proposed by Cox and Evans, the Food Technology Neophobia Scale (FTNS), applied to six categories of food products which had undergone various degrees of industrial handling and processing. The variables generated by the FTNS were subjected to principal component analysis (PCA) which extracted four factors subsequently used for sample segmentation via an analysis of non-hierarchical groups.

The results show the separation of seven groups distinguished by different attitudes to food technology, determined by their perception of risk, perception of uncertainty and by personal judgements concerning the utility, benefits and potential harm of using such technology. There emerged a group which we called convinced technophiles consisting of 48 individuals, about $13.5 \%$ of the sample. The group represents so-called early adopters who are the first ones taking part in the market for food products with a high innovation content ${ }^{\mathrm{e}}$. Starting from this group, other consumers, or followers, may take up the demand, allowing the firm to penetrate the market and achieve their objectives in terms of sales and market share (Mahajan et al. 2000). 
The availability of new techniques to refine market segmentation may lead to more effective marketing policies being chosen by the company, allowing both a clearer view of the different life cycle stages of the product itself and offering the possibility to affect it especially in regard to the crucial phases of introduction and product growth, during which food companies seek to recover the costs of R\&D (product concept and design) and those carried out to start production. From this point of view the group of the early adopters seems to play a strategic role: knowing not only their socio-demographic characteristics, but also psychographic profiles represents a crucial factor for the firm both to estimate potential demand and to target choices in terms of distribution channel and communication.

\section{Endnotes}

${ }^{a}$ The Likert Scale is a psychometric ordered scale commonly used in surveys and questionnaires to measure opinions and attitudes. In a Likert scale the respondent is presented with a set of attitude statements on a scale ranging from strongly agree to strongly disagree and he/she chooses one option that best aligns with his/her view.

${ }^{b}$ Number of the groups is chosen looking at the distance index in the clustering process.

${ }^{c}$ Actually, the use of self-anchoring scales allows to get information on the absence/ presence of technophobia. However, in different studies, the absence of neophobia is interpreted as the presence of neophilia. Look in this regard the work of Choe and Cho (2011) that using the scores of the FNS divides the participants in the survey in neophilics and neophobics. The same approach is also used in Tuorila et al. (2001).

${ }^{\mathrm{d}}$ Cluster analysis classifies individuals on the basis of similarities of some characteristics seeking to minimize within-group variance and maximize between-group variance. A certain level of variance within groups is "physiological", especially due to factors that are less relevant in characterizing the group. That is why we chose to show the results for the extreme groups where the distribution of components 1,2 and 4 is clearly defined around negative (group 3) or positive (group 2) values and the opposite is true for component 3 . That allows to better relate purchase behavior to the attitude toward risk, uncertainty, confidence in media and to draw up conclusions that can be true for the group as a whole.

${ }^{\mathrm{e}}$ Many authors argue that individuals characterized by lower aversion toward food technology can represent a segment of early adopters. Cox and Evans (2008) explicitly link the degree of neophobia with the possibility to identify segments of the early adopters and more recently other authors have used tecnophilia-tecnophobia as a predictor of early adoption (Popa and Popa 2012).

Competing interests

The authors declare that they have no competing interests.

Authors' contributions

FV carried the study plan, collected data, and wrote the background and the method paragraphs. AC analyzed the results, and wrote the results and discussion and conclusion paragraphs.

Acknowledgements

The authors are grateful for the valuable comments of the anonymous reviewers. 
References

Bak H (2001) Education and public attitudes toward science: implications for the "Deficit Model" of education and support for science and technology. Soc Sci Q 82(4):779-795

Balachandra R, Friar JH (1997) Factors for success in R\&D projects and new product innovation: a contextual framework. IEEE Trans Eng Manage 44(3):276-287

Betoret E, Betoret N, Vidal D, Fito P (2011) Functional foods development: trends and technologies. Trends Food Sci Technol 22(9):498-508

Choe JY, Cho MS (2011) Food neophobia and willingness to try non-traditional foods for Koreans. Food Q Prefer 22:671-677

Cox DN, Evans G (2008) Construction and validation of a psychometric scale to measure consumer's fears on novel food technologies: the food technology neophobia scale. Food Q Prefer 19:704-710

Evans G, de Challemaison B, Cox DN (2010a) Consumers' ratings of the natural and unnatural qualities of foods. Appetite 54(3):557-563

Evans G, Kermarrec C, Sable T, Cox DN (2010b) Reliability and predictive validity of the Food Technology Neophobia Scale. Appetite 54(2):390-393

Fife-Schaw C, Rowe G (1996) Public perceptions of everyday food hazards: a psychometric study. Risk Anal 16(4):487-500

Fischler C (1990) L'Homnivore: le goût, la cuisine et le corps. Odile Jacob, Paris

Frewer $\sqcup$, Bergmann K, Brennan M, Lion R, Meertens R, Rowe G, Siegrist M, Vereijken C (2011) Consumer response to novel agri-food technologies: implications for predicting consumer acceptance of emerging food technologies. Trends Food Sci Technol 22(8):442-456

Frewer L, Salter B (2003) The changing governance of biotechnology: the politics of public trust in the agri-food sector. Appl Biotechnol Food Sci Policy 1(4):199-211

Hansen J, Holm L, Frewer L, Lynn J, Robinson P, Sandoe P (2003) Beyond the knowledge deficit: recent research into lay and expert attitudes to food risks. Appetite 41:111-121

Kleijnen M, Leeb N, Wetzels M (2009) An exploration of consumer resistance to innovation and its antecedents. J Econ Psychol 30(3):344-357

Mahajan V, Muller E, Wind Y (ed) (2000) New-Product Diffusion Models. Kluwer Academic Press, Boston \& Dordrecht

Mintel International Group Ltd (2013) The NASFT State of the Industry Report - The Market

Popa ME, Popa A (2012) Consumer behavior: determinants and trends in novel food choice. Novel Technol Food Sci 7:137-156

Pliner P, Hobden K (1992) Development of a scale to measure the trait of food neophobia in humans. Appetite 19(2):105-120

Rollin F, Kennedy J, Wills J (2011) Consumers and new food technologies. Trends Food Sci Technol 22(2-3):99-111

Siegrist M (2008) Factors influencing public acceptance of innovative food technologies and product. Trends Food Sci Technol 19(11):603-608

Siegrist M, Stampfli N, Kastenholz H, Keller C (2008) Perceived risks and perceived benefits of different nanotechnology foods and nanotechnology food packaging. Appetite 51(2):283-290

Slovic P, Fischhoff B, Lichtenstein S (1986) The psychometric study of risk perception. Risk Eval Manage 1:3-24

Tenbült P, de Vries NK, Dreezens E, Martijn C (2005) Perceived naturalness and acceptance of genetically modified food. Appetite 45(1):47-50

Tuorila H, Lähteenmäki L, Pohjalainen L, Lotti L (2001) Food neophobia among the Finns and related responses to familiar and unfamiliar foods. Food Q Prefer 12(1):29-37

Verhoog H, Matze M, Lammerts van Bueren E, Baars T (2003) The role of the concept of the natural (Naturalness) in organic farming. J Agric Environ Ethics 16(1):29-49

Weber EU, Blais A, Betz NE (2002) A domain-specific risk-attitude scale: measuring risk perceptions and risk benefit. J Behav Decis Mak 15(4):263-290

Winger R, Wall G (2006) Food product innovation: a background paper. Agricultural and food engineering working document 2. FAO, Rome

10.1186/2193-7532-2-2

Cite this article as: Coppola and Verneau: An empirical analysis on technophobia/technophilia in consumer market segmentation. Agricultural and Food Economics 2014, 2:2

\section{Submit your manuscript to a SpringerOpen ${ }^{\circ}$ journal and benefit from:}

- Convenient online submission

- Rigorous peer review

- Immediate publication on acceptance

- Open access: articles freely available online

- High visibility within the field

- Retaining the copyright to your article

Submit your next manuscript at $\boldsymbol{\sim}$ springeropen.com 